\title{
Finanças do Brasil
}

\section{A SITUAÇÃO A'TUAL}

Ouve-se que o Brasil é paiz perdido. Deve acima das suas possibilidades economicas. Não tem ordem nos orçamentos, como não na tem nas leis, na politica e na administração.

Tudo lhe corre á matroca. Já não se contam as acusaçõles aos seus homens publicos; uns como delapidadores das rendas do Estado; outros, nas mais altas posições, por mentirem, até em comunicados oficiais, ás cortes estrangeiras. Aqui, o peculato; ali, a rebeldia armada; e, para todos, por sistema, a graça do perdão, e a graça da anistia.

Por outro lado, quem, até ha pouco, entre os politicos, nesta abençoada terra, se pejava de sentar-se á mesa com falsarios do voto, embora repulsassem os moedeiros falsos? Até magistrados se cumpliciavam em distinguir entre estelionatários em matéria de moeda, e estelionatários em matéria de voio, para só áqueles punir. Não tendo a politica 
moral, não poderia a administração ter eficiencia, nem poderia ter nunca o paiz finanças que salvem, ou prestem.

O quadro atual das finanças nacionais é desanimador. A União devia, em fevereiro do ano passado, 136.393.429 libras; os Estados 90.282.412 libras, e os Municipios 26.593.735 libras, ou quinze milhões de contos de réis.

E com que contam a União, os Estados e os Municipios, "para o resgate de tão pesados encargos?

No momento, já se declarou a União impotente para acudir aos seus compromissos. A impontualidade dos seus pagamentos já correu mundo, desacreditando e rebaixando o Brasil á improbidade. Em meio da falencia, que a si mesmo decretou, ainda poude negociar, de mãos postas, acordo vexatorio, com base na moratoria. Já não é o primeiro. E' o terceiro funding-loan. Com a megalomania de que andava possessa, não será, provavelmente, o ultimo, a que se verá reduzida.

Tem a União tomado emprestimos numerosos, apenas para cobrir deficits orçamentarios. A regra financeira de que só se deve contrair emprestimo, quando aplicado, primeiro, renda para o pagamento dos juros e amortizações, e, segundo, produza, nas epocas próprias, pelo aumento da capacidade exportavel do paiz, cambiais para o seu resgate, nunca foi observada. Improvisavam-se, entre politicos e amigos dos presidentes, os ministros da fazenda. Os diretores de repartições publicas lhes supriam as deficiencias técnicas.

Depois, o vicio de gastar o que não podia. Gastar nababescamente, sacando sobre o futuro, até para alem do limite extremo do credito e da vergonha. Era gastar, gastar, e "quem viesse depois que fechasse a porteira".

Se, para cobrir os deficits orçamentarios, já ninguem emprestasse ouro, emitia-se papel, ás centenas de mil contos, sem lastro metal, que o garantisse.

Quando estas emissões, pelo seu reflexo, ao ter o Tesouro de adquirir cambiais para o serviço de sua divida, se 
tornavam máu negocio, ou expediente escandaloso, nada mais facil que emitir sem conta, nem medida, em vez de papel-moeda, obrigações do Tesouro, apolices, promissorias, bonus.

$\mathrm{Na}$ carreira louca para gastar, como demente arquimilionario, pedindo dinheiro de emprestimo ao paiz e ao estrangeiro, chegou a União á falencia de hoje, com uma divida externa, que a esmaga, e uma divida interna, que lhe tolhe os passos, e, ainda por cima, com a formidavel massa de quasi trez milhões de contos em papel moeda que circula sem nenhum encaixe ouro. Este papel é a maior calamidade nacional, o azar fatidico de quem trabalha, o espantalho do capital estrangeiro, as grilhetas da escravização geral do paiz.

Alguns Estados já se quebraram antes da revolução de 1930. Examine-se, por exemplo, o caso do Amazonas. Tem hoje, segundo publicações oficiais, receita de 7.500 contos e despesa ordinaria de 7.400. Mas o serviço da sua divida interna e externa exige, cada ano, mais de 16 mil contos. Para pagar estes 16 mil contos, dispõe de um saldo anual de cem contos, e isto ainda se a renda arrecadada vier a corresponder á renda orçada.

O Ceará não anda muito atraz. Contraiu, ha tempos, um emprestimo de alguns mil contos. Depois, um segundo de outros mil contos, de que recebeu pequena parte, deixando com os banqueiros prestamistas, o excedente para o resgate do emprestimo anterior. Mas, até hoje, este resgate não foi feito. O Ceará deve os dois emprestimos, e não sabe como chamar a ordem os judeus que lhe engazouparam a boa fé.

De Alagôas, o caso é mais triste. O seu governador, ha anos, constituiu procurador o seu secretario da fazenda, para contrair, em Pariz e em Londres, emprestimo determinado. O procurador, armado de plenos poderes, conseguiu, em Pariz, tomar de emprestimo 12.500.000 francos, de que mandou para o tesouro de Alagôas 1.370.000, e consumiu com o resto. Não é só. Como tivesse procuração 
para o mesmo negocio, na praça de Londres, lá contraiu novo emprestimo que, como o primeiro, ficou quasi todo no seu bolso. O tesouro de Alagôas não viu senão migalhas dos dois emprestimos. E o seu infiel procurador emitiı assinatura, com numeros em duplicata. Alagôas ficou a dever em dobro o que contrahiu e não recebeu.

Não é preciso prosseguir. Baste-nos apenas mais esse traço da desordem administrativa do paiz. Dos vinte e cinco emprestimos, de que se originaram a divida da União, não existem, no Ministerio da Fazenda, sinão oito ou nove contratos. O resto ou desapareceu, ou jamais se arquivou. De modo que o Brasil deve, e não tem siquer em mãos cópias dos contratos com que se obrigou.

Para agravar a situação financeira do paiz, a crise mundial e a crise indigena desequilibraram a balança dos pagamentos. A quantidade de ouro de que precisa, principalmente para resgatar emprestimos da União, Estados e Municipios, e pagar compras de mercadorias importadas, $\dot{e}$ maior que a quantidade de ouro de que consegue diapor, como produto das suas exportações.

Sendo a procura de cambiais maior que a sua oferta, é natural que suba o seu preço em papel, isto é, o cambio caia. A exploração comercial não se faz esperar no mercado de cambio. Não havendo, no paiz, ouro necessario para o pagamento externo, os banqueiros que o possuam, e lhe queiram arriscar o emprego no Brasil, reputam bem a sua mercadoria, só a cedendo a bom preço.

E' certo que o poder aquisitivo, interno, do papel moeda não acompanhou a quéda do seu poder aquisitivo, externo.

Mas é isto bem ou mal?

Antes mal, que bem. Quando fôr quasi nulo o poder aquisitivo externo, se o interno continuar alto, o momento é chegado para a desapropriação, pelos capitalistas estrangeiros, do que, no paiz, valha, e lhes convenha. Obtêm eles, com pouco ouro, muito em papel, de alto poder aquisi- 
tivo interno. Com este papel, comprarão, os valores que quizenem, se o governo não tomar, a tempo, medidas de defesa, como, em situação quasi tão aflitiva, ainda ha pouco, o fez o governo da França, contra a invasão da libra e do dolar, em busca de predios nos Campos Elisios.

Tudo, em primeiro logar, porque os governos têm gasto mais do que podem.

Em segundo logar, por obra e graça do papel moeda.

$\mathrm{E}$, em terceiro logar, porque é desfavoravel a balança de pagamentos.

Eis, da enfermidade brasileira, o diagnostico que anda na boca de todos: acima de tudo, desequilibrio orçamentario, e instabilidade da moeda.

Não são novidades. São verdades que todos sabem.

Sim, são verdades sabidas. Mas só os selvagens e as crianças prefenem novidades ás verdades.

\section{II}

\section{PAPEL MOEDA}

A primeira causa dos males financeiros do Brasil é a sua prodigalidade. E' perdulário. Gasta mais do que pode. E gasta mal, principalmente na organização de sua defesa militar. E deixa de gastar bem, principalmente na difusão do ensino primario e profissional.

A segunda causa da miseria, quasi incuravel, que o Brasil curte, é o regimen monetario, em que tem vivido, e insiste. o papel moeda é o flagelo que o empobrece, ou impede que enriqueça.

S.enão vejamos.

Não é preciso expôr doutrinas complicadas, nem vale a pena perdermo-nos de vista, em divagações eruditas. Falemos para ser entendido. Nada de arrebites técnicos, com que a ignorancia presumida embasbaca a simplicida- 
de ingenua. Relembrem-se, apenas, alguns principios elementares.

Em primeiro logar, que é papel moeda?

Nos tempos primitivos, trocava-se por sistema, e hoje raramente, mercadoria por mercadoria, como arroz por algodão, carne por dias de serviço. Tal, ainda ha pouco, o Brasil, permutando café por trigo.

As operações em especie, porém, dificultavam demasiadamente a produção da riqueza. Seculos passaram sobre seculos, para que o homem adotasse, por mercadoria com a qual todas se troquem, os metais preciosos, e, acima de todos, o ouro.

O ouro, em barra, ou cunhado, tem sido, por toda parte, a mercadoria, que mede o valor ás demais, e pela qual todas se permutam. A sua durabilidade indefinida, a sua identidade a si mesma, de modo que de ouro não ha senão uma só qualidade, a sua divisibilidade perfeita, a facilidade do seu transporte e o seu pouco peso para tão grande valor, lhe deram, ha muito e provavelmente para sempre, o primado de mercadoria com a qual todas, universalmente, podem ser trocadas.

E' a moeda por excelencia. Outras mercadorias, como a prata, podem servir de moeda. Mas nenhuma tem as vantagens do ouro. Vale intrinsecamente, por si mesmo. $\mathrm{E}$, por isto, é natural e honesto, que a lei lhe atribua poder liberatorio, ou faculdade de resgatar dividas.

O pagamento em ouro, porém, sobre não acompanhar a rapidez das operações comerciais, é oneroso e arriscado. $O$ seu transporte custa dinheiro, ou trabalho, e expõe o seu condutor á ousadia dos larapios. Daí o seu deposito em bancos de emissão, em troca de cedulas conversiveis, portáteis, posto ainda muito sugieitas, no seu transporte, á cubiça e audacia dos ladrões.

As cedulas bancárias, nestas condições, são titulos de deposito ouro, conversiveis á vista, e a cambio fixo. E' evidentemente muito mais facil a liquidação das operações comerciais com cedulas bancarias, do que com ouro em espe- 
cie. A leveza e ligeireza do transporte, e a eliminação dos riscos ainda são mais consideráveis, quando se substituem as cédulas pelos cheques, e se pratica a compensação destes entre os bancos. E' o sistema sadio dos povos adiantados.

A moeda-papel, que é titulo de ouro em deposito, insistamos, é moeda internacional, porque, tendo valor intrinseco, vale como mercadoria, em todo o mundo civilizado.

Acontece, porém, terem bancos autorizados emitido cedulas com valor muito além do ouro que lhe dorme nos porões. Neste caso, a moeda, por eles emitida, em circulação, já começa a perder a equivalencia em ouro. Foi, entre tantos, o caso recente do Banco de Inglaterra. No curso da grande guerra, o Tesouro inglês emitiu o que precisou, mas, logo, transferiu para o Banco de Inglaterra a responsabilidade da emissão a que se viu constrangido. O Banco de Inglaterra é banco privado, e as suas emissões só podiam exercer, até o limite do seu capital, ao valor do seu deposito ouro. A equivalencia entre as cedulas e o ouro, á parte esta pequena margem, se mantinha. Mas, assumindo o encargo de duzentos e cincoenta milhões de libras, emissão do Tesouro, o valor das suas cedulas em circulação excedeu em muito ao valor do ouro que as garantia. A desconfiança subiu de ponto na tendencia ultra liberal do gabinete trabalhista. Os grandes capitalistas preferem, é claro, depositar seu ouro em logar onde não se receie, nem por sonho, o perigo. A desconfiança na estabilidade ingleza determinou a evasão do ouro, e, com ela, a porcentagem entre o valor das cedulas emitidas e o valor do ouro que as garantia, caiu ainda mais. Daí, entre outras razões menores, a quéda da libra papel.

Atente-se, agora, nas flutuações naturais e inevitaveis do valor da moeda. Sendo o valor uma ralação, o proprio ouro, que é a melhor das mercadorias, não tem, nem pode ter valor fixo. Valor fixo, de seja o que fôr, é absurdo igual ao não-senso de pae sem filho. A elevação geral dos preços 
é a diminuição paralela do poder aquisitivo do ouro. E, vice-versa: a quéda geral dos preços, ou barateamento da vida, corresponde á elevação do poder aquisitivo do ouro.

$O$ poder aquisitivo do ouro depende tambem de sua oferta e procura. A descoberta de minas de onde o precioso metal se extraia em quantidade, lhe enfraquece, por força das cousas, o poder aquisitivo. Tambem o enfraquece a escassez das mercadorias com que ele se permuta. Ao contrario, a excessiva oferta de mercadoria natural é que au. mente o poder aquisitivo do ouro.

Estas variações, entretanto, não são de desesperar. São mesmo relativamente pequenas.

Muito mais variavel, porém, é o poder aquisitivo do papel que o representa, quando não ha paridade entre as cédulas circulantes e o ouro em que elas se podem converter. As variações naturais do poder aquisitivo do ouro se agravam com as variações do cambio entre as cedulas emitidas e o ouro que as representam.

Que se dirá, então, do papel moeda?

Infelizmente, a realidade do papel-moeda não é ainda perfeitamente conhecida, senão por poucos. Ainda ha quem pense ter o papel-moeda valor intrinseco, ser dinheiro, como as belas moedas de ouro. Se lhe lembram o marco alemão, cujo valor desceu ao do papel em que se imprimiam, nem talvez fique a pensar, se, acaso, o papel moeda não se parece com moeda falsa. .

A moeda autêntica, de poder aquisitivo internacional, tem valor proprio, valor real, como mercadoria que é. Só os metais preciosos, e, principalmente, o ouro, representam bem o papel de moeda. Não nos esqueçamos de que são caracteristicos da moeda autentica:

1) é medida de valores,

2) tem poder liberatorio,

3) é mercadoria com valor intrinseco igual ao que declara. 
A primeira caracteristica é convenção como o metro, o gramo, ou o alqueire. A unidade de medida de valores é, no Brasil, o real, nos Estados Unidos o dolar, na França o franco, na Inglaterra a libra, no Japão o yen. Ainda não se chegou a uma unidade universal da moeda, como não se logrou ainda a adoção universal do metro. A civilização caminha para lá.

A segunda caracteristica, o poder liberatorio, é determinação da lei. Tem seu fundamento cientifico, primeiro, no valor intrinseco, universal, da cousa eleita por moeda e, segundo, na necessidade de haver moeda, ou mercadoria com a qual todas se troquem. Naturalmente para dar-se á moeda o poder de resgatar dividas, preciso é, honestamen. te, que ela valha, por si mesma, a cousa devida.

Já a terceira caracteristica não decorre da lei. Deriva da qualidade intrinseca do metal, da sua utilidade, da sua raridade, da sua oferta e procura, que é a grande lei dos valores.

Universalmente, repitamos, a moeda, que satisfaz, é o ouro. E' por não ser pratica a sua movimentação material, que se imaginou a sua representação em papel. Mas o papel que o representa, só não degenera, quando conversivel em ouro, sem embaraços, nem quebras de valor, sempre que o seu detentor o queira.

Daí os bancos emissores que guardam o ouro, e emitem cedulas correspondentes, conversiveis.

Ora, o papel moeda não satisfaz ao principio basico da moeda: o da sua equivalencia, como mercadoria, ao valor nominal que a lei lhe atribue. O papel em que se imprimem notas de cem mil réis, duzentos, quinhentos, ou um conto, não vale talvez nem cem réis.

Logo, cientificamente, papel moeda é moeda aparente.

Praticamente é um titulo de credito, em que a confiança é imposta por lei. Imposta, primeiro, porque a lei lhe declara poder liberatorio, isto é, ninguem lhe pode recusar recebimento, e, segundo, porque, ao mesmo tempo, o tesouro, ou o banco que a emite, não a troca por ouro a cambio fixo, 
sempre que o seu portador o exija. São notas inconversiveis, ou de CURSO FORCADO. As notas conversiveis equivalem ao ouro que dizem valer, porque o seu emissor não se recusa a convertel-as em ouro, sempre que o seu portador o peça. As de curso forçado, porém, alem de terem poder liberatorio, conferido por lei, não valem, por si mesmas, os bens por' que se trocam. As conversiveis, as sem curso forçado, é claro que inspiram confiança, mesmo para alem das fronteiras do paiz. O papel moeda, não.

Por faltar a terceira caracteristica da moeda autêntica, é da sina do papel moeda não ter poder aquisitivo estavel As variações deste poder podem ser máximas, desde o valor ao par, até á bancarrota.

$\mathrm{E}$ porque tamanhas variações?

Porque nada vale em si, como mercadoria, o papel inconversivel, em que se imprime. $O$ que lhe empresta poder aquisitivo, é a lei dọ paiz onde circula. Se é emissão de um banco, pode o banco vir a quebrar, e termina o papel-moeda por nada valer. Se a emissão é do tesouro publico, pode o paiz ir á garra, abismar-se em guerras civis, naufragar em comunismos, e o papel moeda multiplicar-se aos trilhões, como na sina dos perdulários tutelaveis, que assinem promissorias a rodo, acima do que podem. A confiança desaparece, e o desaparecimento dela reduz o poder aquisitivo do papel moeda, no mercado internacional, a quasi nada.

A instabilidade do poder aquisitivo acompanha o papel moeda, como a sombra ao corpo cujo é. Não ha nem póde haver estabilidade na moeda de curso forçado.

Durante alguns anos, pode, não ha duvida, ser constante o seu poder aquisitivo. Dever-se-á esta constancia a dois fatores principais: $10^{\circ}$ ) o equilibrio dos orçamentos publicos nas administrações previdentes e probas; $2 .^{\circ}$ o saldo na balança de contas internacionais, por efeito principal da maior capacidade exportadora em relação aos pagamentos no estrangeiro. Mas a constancia no poder aquisitivo do papel inconversivel é fragil. Um ano de má co- 
lheita exportavel, qualquer desregramento nas importações, uma instabilidade nos sistemas dos governos, já pode desiquilibrar de um só golpe os orçamentos e a balança das contas, produzindo deficit em vez de superavit. E lá se vae a estabilidade da moeda, cambio abaixo do par, subindo para animar, descendo para sugar, e mais descendo que su. bindo, até limites vis.

\section{III}

\section{CONSEQUENCIAS DO PAPEL MOEDA}

A lei magna do papel moeda é a instabilidade do seu poder aquisitivo.

Ora, esta instabilidade da moeda desarvora a confiança no proprio trabalho, entrava o enriquecimento da nação, embaraça a importação do capital estrangeiro. Tres males serios para a vida economica de paiz, como o nosso.

Considere-se, á parte, cada uma destas consequencias.

Um homem, capaz e diligente, leva, digamos, trinta anos a fio a trabalhar, e converte as suas economias em dinheiro corrente, que põe a juros. No fim de trinta anos de efetivo trabalho, acumula seiscentos contos de réis, com cuja renda põe a coberto das agruras a sua velhice, que não fica pesada a ninguem. Imaginemos o cambio a doze. 0 capital de 600 contos tem, então, o poder aquisitivo de 30.000 libras ouro.

Com este poder aquisitivo, o dinheiro a que reduziu o seu trabalho eficiente de 30 anos, como premio de toda uma vida de honestidade e parcimonia, o abriga das incertezas e da miseria. Aconteceu, porém, que, com o regimen do papel moeda, em virtude de uma crise politica, agravada por uma crise economica, o cambio caíu a quatro. $O$ mesmo dinheiro, 600 contos de réis, a cristalização de toda uma vida de trabalho inteligente, passa a ter poder aquisitivo apenas de 10.000 libras. Quer dizer, se tivesse reduzido o seu trabalho a ouro, não se veria desfalcado, e nada sofre- 
ria, na velhice, com a crise, mas, como a moeda corrente do paiz é papel, perde, com a quéda do cambio, 20 anos de trabalho, 20 anos de economias, 20 anos de prudencia, em 30 de vida util. Generalize-se a hipotese, e agradeça-se ao papel moeda o logro ou furto a quem trabalha.

Segundo caso, e este a entender diretamente com a nação. Sabe-se que nenhum paiz pode apenas exportar, ou apenas importar mercadorias. A só importação determinaria o exgotamento rápido do ouro que houvesse no paiz importador. A só exportação acarretaria o excesso de ouro no paiz exportador, e, como primeira consequencia, a baixa do poder aquisitivo do ouro, ou encarecimento de tudo, e, como consequencia dela, o retraimento da propria exportação. $\mathrm{E}$ isto, ainda, se os demais paizes pudessem ou se sugeitassem á contingencia de apenas comprar. A politica sensata tem de ser importar e exportar. Se possivel, exportar mais do que importar, para que o saldo da balança do comercio desafogue o paiz.

De não poder hoje nenhum paiz deixar, normalmente, de importar e de exportar, resulta, para a sua moeda circulante, duas especies de poder aquisitivo. $O$ interno e o externo. Se a moeda fôr papel de curso forçado, o seu poder aquisitivo externo é de extrema instabilidade. Nada mais sujeito a beirar a casa do zero. Seria compreensivel que as variações do poder aquisitivo externo fossem acompanhadas, passo a passo, nas variações, pelo poder aquisitivo interno. Acontece, não obstante, permanecer alto o poder aquisitivo interno, ainda quando o externo decaia a taxas vis. E' o que precisamente se está dando com o papel moeda brasileiro, nos dias que passam. Apesar do cambio abaixo de quatro, ou do dolar nas alturas de 15 a $16 \$ 000$, o poder aquisitivo do papel moeda nacional, nas relações internas, não desceu a todo o pano, a ponto de encarecer em demasia a vida.

A manutenção do alto poder aquisitivo interno, em contraste com o baixo poder aquisitivo externo, vai, entretan- 
to, criar, note-se bem, vai criar a escravização economica ao povo que exporta.

Figuremos uma hipotese concreta. Consideremos a exportação do café, entre nós. Admitamos, para argumentar, 10 milhões de sacas exportaveis, e tambem para argumentar, avaliemos em 100 mil réis o preço de cada saco de café, no porto de exportação. Cambio a 12, e, pois, cinco libras por saca que se exporta. Os dez milhões de sacos de café, trabalho agricola de todo um ano, são trocados por cincoenta milhões de libras. Estes 50 milhões de libras é o por quanto o Brasil, isto é, no caso, os fazendeiros, indivudualmente, entregam aos consumidores o seu trabalho de um ano agricola.

Mas como a moeda circulante no paiz é de curso forçado, o cambio, no primeiro desequilibrio da balança de contas, e mercê dos sucessivos deficits orçamentarios, cobertos por emissões de papel moeda, se despenhou até a casa dos quatro. A libra, de vinte, passou a sessenta mil réis. Fraquissisimo poder aquisitivo externo o da nossa moeda. Mas, nas relações internas, a confiança continua, e o poder aquisitivo da moeda circulante, dentro do paiz, permanece mais ou menos o mesmo.

Os fazendeiros ainda alcançam, suponha-se, vender a cem mil réis cada saco de café, no porto de exportação. Vendiam por cem mil réis; vendem por cem mil réis. Daí o doce engano de venderem sua safra, com o cambio 4, pelo mesmo preço de quando o cambio a doze. Por mil sacos de café, então recebiam cem contos. Por mil sacos, hoje, recebem cem contos de réis. Logo vendem hoje pelo mesmo preço que vendiam hontem. E se estavam contentes antes, contentes continuam agora.

E' a ilusão de quem não pensa. A inocencia nas criaturas humanas é susceptivel de mil variações e gráos. Na verdade, o paiz sofre sangria formidavel.

O comprador estrangeiro, no cambio a 12 , desembolsava 50 milhões de libras, para adquirir os dez milhões de sacos de cafés. Agora, cambio a 4, não desembolsa nem 17 mi- 
lhões de libras. O Brasil deixa de receber, em tróca do produto de um ano agricola, mais de 33 milhões de libras. Claro está que a balança de pagamentos não se pode aguentar. 0 cambio cada vez mais se precipita, pela lei natural da oferta e procura. A moratoria nacional é a vergonha a que não se pode fugir. Moratoria e pobreza e escravidão economica. A vida encarece. Faltam recursos gerais. Miseria. Descontentamentos. Terreno inflamavel ás revoltas. $\mathrm{E}$ o paiz, isto é, os homens que o habitam, meros colonos das nações que lhe compram em ouro os produtos do seu suor.

E' a sangria permanente do Brasil, em beneficio das nações, estrangeiras, por obra e graça do regimen, em que vive, do papel moeda.

Generalize-se a hipotese. Alem do café, é o cacao, é a borracha, é o algodão, é a fruta, é tudo. Sangria por todos os lados, com que o estrangeiro flue o trabalho nacional, mercê da instabilidade do papel moeda. São algemas mais duras que as dos antigo cativeiro, quando o senhor das senzalas vivia e gosava com o trabalho do negro. Ambos têm a mesma caracteristica: um trabalha, e o outro recebe o produto do trabalho, em troco de alguma cousa com que o trabalhador possa continuar a viver e a trabalhar.

Será que não bastam os dois desastres apontados, o furto ao trabalho individual, e a sangria á nação, ambos reais e palpaveis, para condenar o papel moeda, para lastimar que o Brasil tenha vivido tantos anos a se escravizar com ele, para provocar uma reação geral, um clamor de saude e virilidade contra o papel moeda, na medida em que o temos?

Acrescente-se um terceiro aspecto da realidade brasileira, em consequencia do regimen papelista.

Todos proclamam a necessidade da importação de capital estrangeiro, para desenvolver as possibilidades nacionais. Com a nossa pobreza, como nosso empobrecimento, por mais que trabalhemos, não é possivel desenvolver o Brasil. Ninguem hoje teme a aplicação de capitais estrangei. 
ros nas industrias, no comercio, na agricultura. No fim de algum tempo, o capital se nacionaliza, e, desde logo, abre novas fontes de riqueza, fomenta e cria o trabalho aos naturais, aumenta a renda publica, engrandece o paiz.

Mas os capitais estrangeiros não se canalizam para os paizes de moeda instavel, como o nosso, com o seu papel de curso forçado. Medite-se no caso. Um capitalista es. trangeiro, atraido por lucros apregoados, emprega, aqui, dez mil libras, a juros de $10 \%$ ao ano, e prazo longo. Cambio a 15 , e as dez mil libras, convertidas dão 160 contos de réis. Acontece, porém, que, no vencimento do credito, o cambio anda na casa dos seis. O devedor resgata o seu debito, paga os 160 contos que lhe foram emprestados. Mas o credor estrangeiro, neste momento, ao converter o seu dinheiro em libras, apura apenas $4 \mathrm{mil}$. Deu $10 \mathrm{mil}$, e recebe 4 mil. Indigna-se. O Brasil não é paiz onde se possa empregar dinheiro. 0 ouro que para lá se leve, pode ao tornar, reduzir-se á quarta parte, ou menos.

\section{E porque?}

Porque o papel moeda, dinheiro inconversivel, não é cousa em que se possa converter, com tranquilidade e segurança, nem o trabalho, nem o ouro, nada que valha.

Eis aí. Nem se pode reduzir a moeda corrente o trabalho, sem incorrer em riscos de perde-lo. O paiz fica a trabalhar para os outros. E não atrae capital.

Qualquer destas tres consequencias do papel moeda bastaria a repeli-lo como o maior "flagelo das nações". Ainda quando em dose minima, ainda quando até o limite em que o cambio se mantem no ponto de ouro, isto é, quando se troque a moeda nacional com a moeda estrangeira com 0 desconto apenas do custo de transporte, que se poupa, e pequena margem de lucro pelo trabalho bancario, o papel moeda, no limite estrito das necessidades internas, nenhum mal iminente acarreta. Neste limite, o seu valor é estavel. $\mathrm{E}$, sendo estavel, as tres consequencias acima expostas não se podem realizar. 
No momento, porém, em que se passa o limite fatal, o seu valor se torna instavel, e o individuo que trabalha e poupa, e reduz as suas economias a moeda, perde o seu trabalho e o seu dinheiro; e a nação que trabalha e vende ao estrangeiro os seus produtos, perde o seu trabalho e se escraviza; e o capital estrangeiro, necessario ao desenvolvimento do paiz, foge dele como o diabo da cruz.

Ou o Brasil acaba com o curso forçado da sua moeda, tornando-a conversivel a cambio fixo, ou o curso forçado de sua moeda acaba com as ultimas energias dos seus pulsos vigorosos.

Formidavel polvo internacional lhe suga, por todos os póros, o sangue. O papel moeda são as ventosas insacia veis deste polvo invisivel, que não nos poupa. Não ha fugir ás suas terriveis porosidades e antenas, já dentro do paiz, enterradas no coração do povo que trabalha.

Este polvo é o papel moeda.

\section{IV}

\section{QUEIMA DO CAFE'}

Pela emissão do papel moeda não cessam de pleitear os interessados. Certa imprensa crimina os antepapelistas de semeadores da ruina financeira, em que se debate o paiz. $\mathrm{E}$ alguns papelistas ha, sinceros nas suas opiniões.

Sinceros, mas enganados.

Querem a emissão de papel para a compra dos cafés em estoques, e sua queima posterior.

Em primeiro logar, seria fazer toda a nação pagar as loucuras dos planos falhos de valorização. Se tivessem da. do certos, os produtores de café seriam os diretamente beneficiados.

Como abortaram no desastre que terremota, nas suas bases, a lavoura do café, apela-se, então, para a queima dos estoques á custa do erario nacional. Sofra toda a nação os 
prejuizos de um plano que, se não falhasse, benificiaria uma classe.

Não é justo. Mas admitamos que seja util. Vá là que convenha queimar o café em excesso, á custa de uma grande emissão de papel. Será que assim fica regularizada a oferta e a procura?

Engano, dos maiores.

$O$ desequilibrio entre a oferta e a procura não provem do café em estoque. Esse estoque já é efeito da causa ver. dadeira: o excesso da produção sobre o consumo. E a queima do café armazenado não teria a virtude mirifica de apoucar a produção, nem aumentar o consumo. Certo, traria alivio passageiro ao desequilibrio que se acumulou, durante alguns anos, nos estoques atuais. Mas a causa deste desequilibrio subsistiria, os bilhões de cafeeiros continuariam a produzir muito alem dos milhões de sacas consumiveis.

Quem puder realmente normalizar a situação, teria de graduar a produção pelo consumo. Ou este equilíbrio se fará pelo aumento do consumo, ou pelo reduzimento da produção, se não forem possíveis um e outro, simultaneamente. O aumento do consumo dependerá de propaganda, de bom produto, e preço modico. Não é problema que se resolva do dia para a noite. Ha mil barreiras a vencer, demanda capacidades técnicas que não se improvisam, nem é facil remover preconceitos e rotinas estratificadas.

Ter-se-á que voltar, pois, os olhos para o reduzimento da produção.

No ponto de vista brasileiro, claro é que a redução deve ser operada na produção estrangeira. Nunca na produção nacional, enquanto fôr possivel aquela. A' luz dos principios científicos, porém, a redução deve ser onde a produção fôr desfavorecida pela natureza. E' possivel, dentro das leis naturais, que se diminu'a a produção dos nossos concurrentes no mercado internacional?

E'. Não se poderá, é claro, proibir que plantem quanto lhes apraza, nem se poderá mesmo criar, a nosso alvedrio 
embaraços a que se desenvolvam. Mas está em nossas mãos, ao menos, deixar de protege-los contra nós.

Dir-se-á que não somos tão tolos, para protegel-os contra nós. Pois somos, e é o que o Brasil, na sua politica economica, vem fazendo, com uma obstinação de espantar.

Atentemos. O Brasil adota o regimem de proteção ás suas industrias. Não quer saber do livre-cambio. $\mathrm{E}$ faz bem. $\mathrm{O}$ protecionismo alfandegario, com as industrias vitáveis, e aplicado regressivamente, de modo que mantenha o pé de igualdade entre a oferta dos produtos nacionais e a oferta dos produtos estrangeiros, em livre concurrencia entre uns e outros, é inatacavel. O que se deve repelir, é o protecionismo ás cégas, raiando no proibicionismo, em favor de seja qual fôr a industria, e com o intuito direto de angariar, a todo preço, rendas ao erario publico. Mas nos termos acima referidos, seria impatriotismo preferir o livre cambio. O protecionismo, restrito e regressivo, salvaguarda a riqueza nacional, quando, como hoje nos Estados Unidos, não defenda o alto padrão á vida operaria.

Pois bem, o Brasil que protege o produtor industrial em concurrencia com a produção similar estrangeira, perseguc, veja-se bem, persegue, sem alma, inconscientemente, o produtor agricola em concurrencia com o produtor estrangeiro, nos mercados internacionais.

Protecionismo em maquinofatura, e perseguicionismo na produção exportavel.

Examine-se o estranho fenomeno em algarismos redondos e aproximados. Considere-se, de preferência, a exportação do café. Ainda ha dias, nos foi mostrada uma conta de venda: $52 \$ 000$ por saco, em Santos. Foi o preço que o fazendeiro embolsou. Mas sujeito a custeio. Este ficou, pouco mais ou menos, em $46 \$ 000$. Lucro liquido, para o produtor, sem contar o juro e amortização do capital fixo, $6 \$ 000$ por saco.

No mesmo instante em que o produtor entregava o seu produto por $52 \$ 000$ o saco, o governo recebia mais de $60 \$ 000$ de impostos, meia libra, mil réis ouro, imposto ad-valorem, 
sobre taxa, e mais alguma cousa. A partida era de 600 sacas. O lucro do fazendeiro, sem contar os juros do capital empregado, foi de 3:600\$000. E o governo com a mesma partida de café, embolsou mais de trinta e seis contos de réis. Este, o fáto, que está aos olhos de todos.

Agora, as consequencias :

Primeira conclusão: - o produto sai do paiz, onerado com mais de $60 \$ 000$ por saco, para ir concorrer com produto similar estrangeiro. Este não se embaraça no paiz de origem, com impostos de exportação. Vai, todo lam. peiro, desonerado, cativar as preferencias do consumidor estrangeiro. E vence o desgraçado café brasileiro, sobrecarregado com impostos formidaveis. Mas quem lançou estes impostos que o derrotam?

Nós mesmos. Ao envez de favorecermos o produtor nacional contra a concurrencia estrangeira, favorecemos o produto estrangeiro contra o produtor nacional na concurrencia entre ambos. É ou não perseguição ao produtor agricola nacional? Puro sistema perseguicionista. Protecionismo para uns, os industriais felizardos. Perseguicionismo para outros, os fazendeiros em miseria. Dois pesos e duas medidas, com os olhos fitos na arrecadação dos impostos. Não pode haver mais grave antinomia. Ser e não ser ao mesmo tempo, ou ser uma cousa, e, ao mesmo tempo, ser exatamente o oposto, é sesquipedal absurdo, só comparavel á megolomania dos loucos, que, nos hospicios, se coroam de reis. Assim o Brasil, quando protege e persegue o produtor. Protege uns, e persegue outros. Protege os industriais, e persegue os fazendeiros. A estes, onerando os produtos indigenas, a aqueles onerando os produtos alienígenas. $O$ Brasil é protecionista e não protecionista ao mesmo tempo, e, peior que isto, é protecionista e, no mesmo passo, é perseguicionista.

Segunda conclusão: - os impostos contra o café são a maravilha branca do comunismo. Na sua grande ino- 
cencia em materia economica, o Brasil dá aos povos, e, especialmente á Russia, uma lição de comunismo pratico. Dois principios elementares estão em perpetua guerra na questão social. Primeiro, este: quem trabalha é senhor do que produz, e, como tal, faz do seu produto o que quizer. E o principio da liberdade individual. Segundo: quem trabalha não é dono do que produz, trabalha para a coletividade, e desta recebe alguns bens, para continuar a viver e produzir. É o principio negativo da propriedade individual, o principio socialista, o principio comunista. $O$ sistema revolucionario socialista-comunista é o de que o operario trabalha para a coletividade que o recompensa, segundo suas necessidades, ou segundo stia capacidade, ou, ainda, segundo suas obras.

Em face destas premissas, como classificar, entre nós, o regimen da produção do café? O produtor de café trabalha e armazena o seu produto, e o leva, quando o governo lhe permite, ao porto de exportação. Mas, na hora do produto ser convertido em ouro, a coletividade fica, em algarismos gerais, com a somma de 60 a 70 por saco, e elle, o produtor, com o lucro provavel, quando lucra, de 2,3 a 7 mil réis. Trabalha, pois, para o Estado, e este consente que ele fique com alguma cousa, para continuar a trabalhar.

Se isto não é comunismo, não ha comunismo no mundo. Teme-se, e treme-se, entre nós, o espantalho comunista, que nos anda rondando o paiz. Mas não se repara que ele já está instalado, realizado, com raizes firmes, na produção do café, e realizado, sem lutas sanguinolentas, sem cadafalsos nas ruas, mesmo sem o rotulo de comunismo, e talvez, quem sabe? sem que tivessem os seus autores a consciencia de estarem implantando o comunismo! O Brasil é realmente o paiz maravilhoso das maravilhas. Era, ha tempo, arvore de patacas. Hoje, comunismo, sem que os expropriados o saibam, e, até, com os seus aplausos...

Estas considerações, contudo, dir-nos-ão, não resolvem nada. 
Certo, nada resolvem. Mas servem para mostrar como os impostos que pesam contra o café, que se exporta, logram estas consequencias:

1) perseguem o produtor nacional,

2) protegem o concurrente estrangeiro,

3) e implantam o comunismo no principal produto do paiz.

Suponha-se, porém, que seja ele abandonado. Nada se cobra pela exportação dos produtos nacionais. Não é preciso ir até premiar o melhor café, o melhor cacau, a melhor madeira, que se exportarem. Basta que se lhes desonere a saida dos impostos de qualquer denominação, ou eufemismo.

Neste dia, o café brasileiro seria oferecido, nos mercados estrangeiros, por quasi metade do que por hoje se vende. E' preciso o alto preço no mercado internacional para vingarem os concurrentes estrangeiros. Este alto preço nós é que contra nós o fazemos com os impostos de exportação. Criamos e alimentamos a concurrencia que nos esmaga. Elimine-se, porém, o imposto de exportação, e o nossó café será oferecido, provavelmente, pela metade ou quasi do que por hoje se vende. Em dois ou tres anos de um regimem livre, com mercadoria ótima, e a bom preço, os concurnentes estrangeiros baquearão. Se não baquearem, terão que amargar os azares da crise, sacrificando reservas, esgotando o credito, e perdendo pouco a pouco a propriedade, como se vai processando entre nós. Mas, dada as condições do clima e natureza do solo onde se produzem, certo não poderão sustentar a concurrencia do café brasileiro, desonerado do imposto de exportação.

Dentro de poucos anos, em consequencia, estaria diminuida a produção. Não á nossa custa. Mas á custa da concurrencia estrangeira. E, então, equilibradas, em base solida, pelo jogo das leis economicas, a oferta e a procura, o preço seria remunerador. Se daí por diante, não voltas- 
semos ao regimen das valorizações artificiais, criando novamente estoques, o preço do café, alem de remunerador, seria estavel.

Eis a medida defintiva da regularização. E' equilibrar a oferta com a procura. E' só produzir o que se consome. Como hoje se produz em excesso, cumpre diminuir a produção, e, nesta diminuição, inteligente será que desapareça do mercado quem não tiver condições naturais de vencer. Bastará, para isto, que cessemos com o artificio dos impostos de exportação, com que protegemos os concurrentes que nos aniquilam.

Não tardará que objetem. Mas como se arranjarão os Estados cafeeiros com os orçamentos desfalcados deste imposto?

É outro problema. O que se examina agora, é o do café. E, neste, ou se acaba com o imposto de exportação, para anular os concurrentes do nosso café, e diminuir a produção do artigo, ou o imposto de exportação acabará com a riqueza do café brasileiro. Talvez neste dia, o perigo e o bom senso, o senso comum nos iluminem. Muita gente só aprende as verdades elementares, depois de muito sofrer com as suas violações. Alguns, nem mesmo depois.

Preferem a panacéa, o paliativo, que excita como certos afrodisiacos, para logo enfraquecerem mais, descendo do nivel em que estavam. Queima de estoques? Alivia; mas, como a causa das crises, a super-produção, subsiste, a crise voltará de novo, pela formação de novos estuques, com os excessos da produção de cada ano. Fabricaçâu tipografica de papel-moeda? Desafoga, no momento, mas, como a causa da crise, a super-produção, continua, lá retornará ela sem dó nem piedade.

Pois não é super-produção a causa do mal? O remedio é eliminar a causa, isto é, diminuir a produção.

Diminuir com a broca que se alastra? Diminuir com a geada que aconteça? 


\begin{abstract}
Diminuir com as falencias que sobrevirão?
Diminuir com o abandono das fazendas pouco produtivas?
\end{abstract}

Mas, para que contar com o acaso, o azar e a desgraça, se o remedio está em não estimular a concurrencia estrangeira?

Juizo e ciência. Nada mais. Respeitem-se a leis naturais. Todo artificio humano contra as leis inexoráveis termina em resultados negativos. A natureza é a grande mestra da responsabilidade, beneficiando, ou desgraçando, os que lhe observem ou inflinjam as leis. O Brasil sofre miseria por não querer seguir a natureza, nas leis que a ciência economica formula. E, enquanto persistir na rebelia, será uma nação castigada e economicamente escrava.

SAMPAIO DORIA

Professor catedratico de

Direito Constitucional 